\title{
Administrative Division Reform and Sustainable Development in Albania
}

\author{
Sonila Xhafa \\ State University of Tirana, Department of Geography, Albania \\ Email: sonilaxhafa@gmail.com \\ Eqerem Yzeiri \\ State University of Tirana, Department of Geography, Albania \\ Email: eqeremyzeiri@unitir.edu.al
}

\section{Doi:10.5901/ajis.2015.v4n2p143}

\begin{abstract}
One of the most important current developments in Albania, is the project on the reform of the new administrative division of territory. Until now planning policies and territorial development are oriented on administrative division legislated in 1992. Until 2000 were made some partial changes, which are not associated with structural changes or decentralized effects. Actually, there are 12 counties, 309 communes and 65 municipalities. This organization relies on fragmented administrative division inherited from the communist regime. Under these conditions, the need for a reform on territorial division, has become one of the strongest challenges of policymaking, towards its realization based on Albanian legal framework and international best practices. Current studies in this field are conducted by national and international organizations: Study of Fiscal Decentralization (USAID, 2012); The Report of Territorial Reform in Albania, (Association of Municipalities of Albania); as well as some partial reports by the OSCE, UNDP, etc. In this study, intended the diagnosis of all conditions and factors that inhibit: rational use of the territory; natural resources management; control of demographic processes, management of residential informality, the quality of public services, functional development of land, sustainable development in general, and reinforce the need for a new administrative division reform. In this study will be used: -spatial and territorial analysis based on the criteria that will be used for the new administrative division (demographic criteria, economic functions, cultural typology of territory etc. • interpretative analysis of approximation of this reform with the provisions of European Charter of Local Self-Government. This issue has public and community importance, given that this reform will pave the way for sustainable development in general, and creation of unified economic systems, which will promote cooperation initiatives with other regions of the Western Balkans, and beyond.
\end{abstract}

Keywords: Local Self-Government, territorial development, sustainable development, administrative division.

\section{Introduction}

The reasons "why territory is reformed" and "how it is reformed" changes from one country to another, reflecting their economical and social development. The international experience of the models of France, Italy, Nigeria, show that the administrative territory reforms are made for three reasons: a) as a consequence of dramatic changes of power (responsibilities) or regimes (the case of France); b) to preserve the balances of historical heritage in different governing regions (the case of Italy); c) to enforce the cohesion of state and to weaken the cohesion of its ethnic groups (the case of Nigeria). These models naturally do not exclude the fact cases of reconfiguring of the administrative territory divisions in conditions of normal economical-social development, as in the case of Albania. During two decades, Albania was involved in intensive demographic social and economic changes, dictated by deep political changes after 50 years of separation from the communist regime. In these conditions, the territorial reform is necessary in terms of the implementation of principles of sustainable development in local and central government.

A special place in the study has and the impact of this reform in local government elections, and consequently in local policymaking, given that reforms aimed to meet up in the local elections of 2015.

\section{Trends of Administrative Territory Reforms Implementation in Europe}

The economic crisis in 2007-2010 has raised the need for territory reorganization in a lot of European countries and in the region, in order to achieve a most efficient and rational use of natural resources, more efficient way of management by 
the local authorities and turning these resources into essential national economical assets, respecting at the same time the principle of stable development.

Dexia (2012) summarizes some of the models of implementing the territory reform in different countries, at the center of which stands the necessity and the trend of reducing the number of small communes (according to the space and population), or their suppression by merging them with other communes or urban centers based on different reforming criteria.

Table 1: Models of implementing the territory reform in different countries

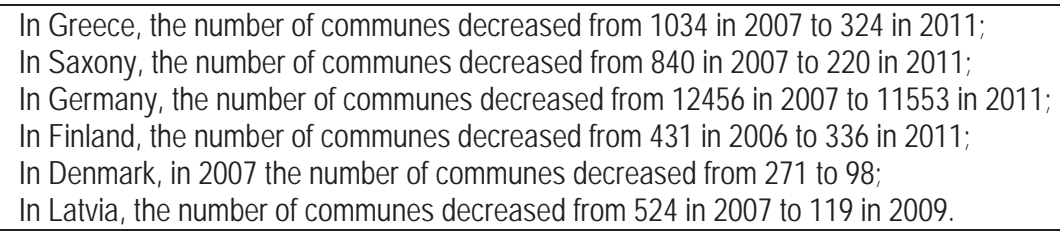

In 2011, the Irish government promoted the union of towns and communes, in order to have a more stable management of urban systems. In addition in 2012, the Spanish government adapted a plan which aimed at decreasing the number of localities in less than 5000 inhabitants, which made $84 \%$ of the general numbers of communes in the whole country. In these conditions, it is aimed at the same time to regulate the local rights and competences.

However, this trend is not noticed in all European countries. Thus, in France and Luxembourg, this trend is developing slowly. For example, in Italy, such a reform (suppression of smaller communes with less than 1000 inhabitants) was contested, even though it could be urged because of the fiscal policies development. The need to implement such a territory reform was replaced by the alternative of implementing the policies of merging these communes in the inter-jurisdictional cooperation (promote inter-jurisdictional co-operation), starting with simple agreements of transferring the functions, building common commissions to offer services, until more complex forms of integrating institutional cooperation.

The politic history and environment have had a powerful influence on the territory reform. After the fall of the communist regime in many counties of East Europe, former communist republics, but also countries like former Yugoslavia followed policies that aimed at decentralizing and urging the local self-governing. These policies were accompanied with a process of territory reorganization that resulted in the establishment of a great number of local selfgoverning units.

After a historical background, since the creation of the Albanian state in 1912, it results that the number of prefectures and districts has remained almost the same, when the number of merged villages, towns, communes and municipalities has changed a lot influenced by the economic-political conditions. According to Law $\mathrm{nr}$. 8653 , the territory of the Republic of Albania, with a population of more than 4 million inhabitants, is divided into 65 municipalities and 309 communes. About $45 \%$ of the general number of communes has less than 2000 inhabitants. In this context, it results that the administrative territory is fragmented and Albania is ranked among countries with a big number of small communes. Generally, the need to implement territory reforms and to a new administrative division is obvious in countries where there is a big number of communes and with a low number of inhabitants. In Spain there are more than 8000 communes with an average number of 5500 inhabitants. Italy has almost the same number of communes with an average of 7000 inhabitants. Switzerland has 2700 communes with an average of 2800 inhabitants, etc. Reducing the great level of territory fragmentation in Albania is one of the most important challenges of the local and central government, towards the increase in fulfilling efficient economical and commune functions.

The actual administrative territory division of the local governing units in Albania is provided for by the law $\mathrm{nr}$. 8653/2000 For the administrative and territory division of local government in the Republic of Albania. Besides the steps made with the reform of decentralization, this law saved the administrative and territory division fragmented, implemented in 1992, which was mainly based on the tradition of state organization from the communist government. This organization operated with agricultural cooperatives. Thus, the Law nr. 8653/2000 did not reflect the pace of economical, social, demographic and infrastructure developments happening after 1992.

However, the administrative and territory division of Albania resulted in many small local governments with limited assets and resources, what in many cases made it very difficult for the local governing bodies to offer efficient and qualitative public services to the inhabitants. 
Table 2: A short history of administrative-territory division of Albania

\begin{tabular}{|c|l|}
\hline Years & Administrative-territory organization \\
\hline $1913^{1}$ & 8 prefectures/ sub-prefectures (district)/ provinces. \\
\hline $1927^{2}$ & Albania had 10 prefectures, 39 districts, 69 provinces and 2351 villages. \\
\hline 1934 & 10 prefectures, 30 districts, 160 communes with 2351 villages. \\
\hline 1940 & 10 prefectures, 30 districts, 23 municipalities, 136 communes and 2551 villages \\
\hline 1945 & 10 prefectures and 61 districts, communes and municipalities were suppressed \\
\hline 1946 & 10 prefectures, 39 districts and it was partially introduced the locality \\
\hline 1953 & The prefecture was substituted with the district. 10 districts, 26 regions and each region had 3 or more localities. \\
\hline 1958 & The district was suppresses and there were created 26 regions, 203 localities, 39 towns and 2655 villages. \\
\hline 1968 & 26 regions, 437 merged villages 3,2641 villages, and 65 towns. \\
\hline 1990 & $\begin{array}{l}26 \text { regions, } 539 \text { merged villages, } 2848 \text { villages, and } 67 \text { towns. The capital town had 3 regions, which included } \\
\text { some neighborhoods. }\end{array}$ \\
\hline $1992^{4}$ & 36 regions, 44 municipalities and 313 communes. \\
\hline $1992^{5}$ & There were created 12 prefectures, where each prefecture included 2-4 regions \\
\hline $1992-2000$ & $\begin{array}{l}\text { There have been made some partial changes in the administrative -territory division without making any change } \\
\text { in structure. }\end{array}$ \\
\hline $2000^{6}$ & Regions were suppressed as administrative units and districts were created \\
\hline At the moment & $\begin{array}{l}12 \text { Districts, } 65 \text { municipalities, } 309 \text { communes. The municipality of Tirana is divided by a special law in } 11 \text { mini- } \\
\text { municipalities with an elected council, but without having the right of the property and fiscal policies. }\end{array}$ \\
\hline
\end{tabular}

The municipality of Tirana is divided by a special law in 11 mini-municipalities with an elected council, but without having the right of the property and fiscal policies.

\section{The Necessity of Implementing a New Administrative-Territory Reform}

The number of administrative levels in the country, the ways of dividing responsibilities among other levels of government, the field of action and the autonomy of local government, as well as the number or size of the communes, define somehow the need for territory reform and mechanisms to be used in a certain country. Some of the reasons that emphasize more the necessity of the implementation of a new territory reform are:

1. Fulfilling the needs for the membership in the European Union. At the core of the principle of subsidiary based on the European Cart of Local Government, stands the regulation that a central authority must have additional functions, fulfilling only the duties which can be made in a local level. In this way, the central government takes care of the legal framework of economical and political life, at the same time taking care of the implementation by the local government to ensure the fulfillment of public services in the most efficient way to the resident. The implementation of this principle in local and central government, serves at the same time to a stable development, assessing the impact context on economical and political life, as well as in demographic and territory development. From this point of view, the principle of subsidiary is based on:

- On the principles of delegation (of functions and responsibilities to lower levels) and proportionality (dispersing these functions and responsibilities proportionally in order to avoid disparities of public services and economical and territory developments in general).

- On a balanced definitions of the level of intervention by the central government, in the competences of local government.

- On transferring specific competences from the central government to the local one, only in the case of localities of a special strategic, economical and geographic position, in national level, or in the cases of a specific treatment of certain communities within community units. For instance, the education of an ethnic

${ }^{1}$ The Adapted Canon of the Civil Administration in Albania published on November, 22nd 1913.

2 "Organic Laws of Municipality" passed in 1921

3 It is introduced the first term of the merged village, with compact territory, but detached

${ }^{4}$ According to Act 1, Law nr. 7572, 10.06.1992, "On the organization and function of the local government"

${ }^{5}$ According to Law nr. 7608, 22.09.1992, "On the prefectures".

${ }^{6}$ Law nr. 8653, 31.07.2000 
group. According to Oates (1972), if the individuals with similar preferences (for ex. if their life conditions are specific) live in a small area, then the decentralization can be the best way to fulfill their specific requests.

- On ensuring a wider participation in decision-taking, paying too much attention on specific cases which not always orient towards the necessity of decision-taking on levels that are closer to the citizen.

All these principles are challenges that Albania has to overcome successfully through a necessary mechanism and which ensures efficiency and a quick fulfillment of the request for the EU, precisely through the territory reform. These principles are implanted more precisely, more efficiently correct and in a more qualitative way in economical and social life, in the conditions of territory consolidation. The merging of mini-communes makes them capable of responding better to the local requests, as well as to adapt the public expenses more efficiently to the community needs. Many communes have territory and/or a smaller population to promote more effectively the economical development and the need to coordinate the actions to the neighboring communes.

The aspiration of Albania as a candidate of EU increased even more the necessity of implementing the territory reform, which will reinforce decentralization and at the same time the centralization of some central functions in a coordinative and macro-economic level. The growth of local autonomy is one of the main priorities in the agenda of EU, so very often the decentralization is seen as a point of reference during the drafting of national strategies or the implementation of regional projects.

The funds given to Albania by EU in many fields of life have been oriented centrally and regionally, and in territories with homogeneity in development and functionality, thus, in this aspect, territory reforms have more priority

2. The need for territory consolidation and at the same time avoiding territory fragmentation. Very often the territory reform is seen as very necessary, assessed as a mechanism that generates territory consolidation. In the conditions of nowadays intensive economical development, locally, regionally and even further, Albania is suffering the negative effects of territory fragmentation, which lessens the potential possibilities of being included in these developments. Territory fragmentation, as a consequence of fragmentation at the same time of the government, causes corruption. Considering the problem from this point of view, it is noticed from many studies that the level of corruption among civil workers is higher in smaller localities rather than bigger ones (Tanzi, 1995). This is because the personalization and treatment of services are increased in the conditions of lacking of professionalism. On another point of view, too much territory fragmentation results in inequality regarding the development and the lack of administrative and fiscal capacities. For this reason, it is become a big obstacle for the development of mechanisms of offering local services, for the stable development and for further decentralization.

In the case of Slovenia, it is noticed that fragmentation of local authorities (over 100 have fewer than 5000 inhabitants and 25 fewer than 2000) gives rise to problems in providing public services, and that most 'do not have the capacity to conduct strategic planning or absorb EU funds in the given timeframe' (OECD 2011).

3. Territory reform defines the conceptual content of decentralization and it reinforces it as a process. Decentralization can never be considered as an alternative of centralization. The territory reform and its effects in decentralization very often are understood as a process; meanwhile it represents a set of reforming policies in order to transfer responsibilities, resources or authorities, from the higher levels to the lowest ones. To make this happen, policymakers need decentralization, as well as centralization of certain functions. In this way, the new territory reforms must be led by this concept, because many central functions (or central like: coordination, monitoring and assessment) will be reinforced through decentralization. Based in this context, but also additional to the requests of laws of European cooperation, such a process must be developed according to policies of "decentralized government", rather than classic policies of decentralization.

4. The need for a rational and stable use of territory, with the purpose of minimizing the more possible the cases of misuse, which affect the stable development in general, in all levels. Suppressing of small communes and their merging with other localities, urban or rural, leads to efficient development of common administration in cases like: collecting and administrating taxes, urban planning, giving building permissions or public transport regulations, harbors and airports, management of human resources, procurement, internal local control, management of sewage system, management of wastes and rubbish, etc.

5. Unequal distribution of population in territory, from intensive internal migration during the last two decades of transition, intensive population of urban centers and depopulation of rural mountainous areas, are a great 
obstacle in minimizing the potential possibilities of new localities to plan and implement new re-distribution policies of services or of the income.

A new administrative division in order to reduce the number of communes, to territory consolidation brings advantages that generate developments, like:

1. Long-term and stable administration of the development of the land. The new territory division shall aim at a "vision" to offer full and quick public services in the region, as well as the identification of cases where this aim is fulfilled partly in the service of planning specific administrative and territory interventions that stop this vision.

2. Increasing the best local institutional image in issues of land administration and territory governance, from the formal political structures to the administrative ones. Bigger localities have more technical and operative efficiency in offering basic services and specific regional ones, in well-functioning of tax system, because of the increase of administrative efficiency and governance.

3. Lessening of disparities of development and marginalization, also as a result of poverty.

4. Efficient common economical planning and development according to the types of development and common priorities (tourism, agricultural section, industry, etc). Bigger localities are able to fulfill more functions, mainly economical, and in some cases to turn them into efficient regional and national activities.

5. Building bigger localities that increase the potential possibilities of getting more investing projects in regional cooperation, when if they are alone they would be exempt, or less affected by the internal and foreign funds. Building bigger localities avoids the fulfillment of beggar-thy- neighbor policies.

6. Increasing the cooperation and pro-activity among localities, already consolidated. The more communes in a place, the more complicated is the cooperation among them.

7. Urging locality leaders, but also the community in thinking of the area as a region.

The need for such an administrative division is emphasized by a lot of foreign and Albanian experts, including the Progress Report of 2012 of the EU Commission, the Study on Fiscal Decentralization prepared by USAID in 2012, the Report "Territory Reform in Albania" for the Organization of Albanian Communes, as well as other previous reports of OSCE, UNDP (2005-2006), and RDP/SDC and ADA (2011).

\section{Reform Implementation, Legal Framework, Criteria of Territory Division}

During these two decades of transition, the territory in Albania is seen as fragmented, after decentralizing reforms, but also because of specific economical-political conditions. One of the basic indicators in the continuous discussions on the new territory reform is also the size of the area territory. The size of the local governed territory does not refer only to a geographic dimension, but also to the characteristics of local government, including the way the central government distributes the functions to localities.

The number of communes that can be joined to a territory or another governance level can be 2 or more. This depends on the purpose and the argument of their fusion. For example, it is not uncommon that whole small regions to be included in one level to promote tourism or environment protection.

One of the presented proposals until now is the one where the country is reconfigured administratively in 6 regions:

- Tirana, a separate region with a special status;

- The Region of Arbri;

- The Region of Muzaka;

- The region Elbasan-Korce;

- The region of Kaons;

- The region of Shkodra.

Besides the great problematic that each of the regions bare, concerning the number of the population, the territory size, different economical levels of their parts (municipalities), cultural differences, historic heritage and the geographical position, etc, and also the terms of these regions are debatable, because there is not a unified criterion. Naming an administrative-territory unit in the Middle part of Albania as "Region of Arber" is a misuse of the name, which according to professor Cabej is a synonym of the Albanian population in the Albanian lands, where Albanian language is spoken, from the North to the South. The honorable professor says that "...the name with which we call our people (Albaner, albanais, Albanese, etc) has been used before generally as the name of the people in Albanian lands". The areal of the usage of the name is very wide, starting with Laberia to the North, in the form of Arbnesh. So, it is counterproductive, that in this 
name, with a whole national resonance, to be used in a region, which is also very debatable. ${ }^{7}$

The same consideration goes also for the name "The region of Kaons". Kanons are "an Epir tribe that were settled by the shores of Jon sea, from Thyamis river (today Kalama) in the South, to the Akrokeraune mountains in the North, and the internal regions of the valley of Drinos. Kaons were one of the three most important tribes, with Molose and Tesprote - and they had a kind of a unit (koinon) built on the bases of federative system. According to Tukidit, Kaons' koinon did not recognize the power of the king. ${ }^{8}$

Two other proposals are given by Co-Plan. The first version defends the idea of dividing the administrative territory in 4 regions:

- The region of Shkodra;

- The central Region;

- The East-West region;

- The Southern region

The second version defends the idea of dividing the administrative territory in 6 regions, based on the water basins of our country respectively:

- The region of river Drin;

- The region of Mat-Drin;

- The region Shkumbin-Erzen;

- The region of Devoll;

- The region of Seman;

- The region of Vjosa.

From a short analyses of the two variants, it results that they have the advantage of simple terms. In the first version of the CoPLAN, it is noticed the horizontal geographical direction of the regions, avoiding the problems of meridians, nevertheless, it has still got problems. The very strong geographical differences that they have in physiographic, human, economic, regional, ethnographic and cultural aspects, and of the distribution of inhabited areas, the proportion of urban population to rural one, etc, are considerable and they do not presume the territory continuity and unity of the region, neither the creation of a fair proportion center-countryside.

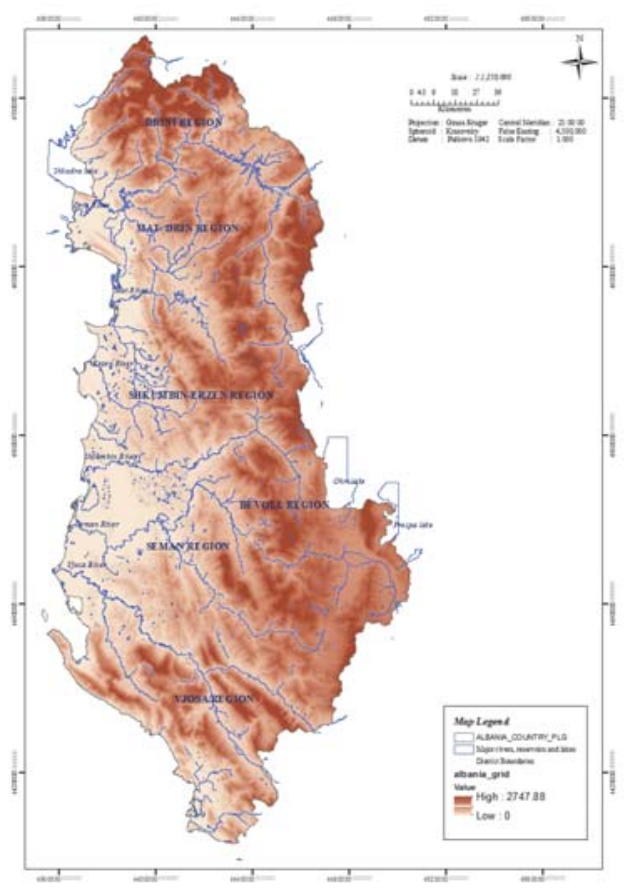

${ }^{7}$ Eqerem Çabej, Shqiptarët midis Perëndimit dhe Lindjes, Tiranë 1994, pg. 9-16.

${ }^{8}$ Akademia e Shkencave e Shqipërisë, Fjalori Enciklopedik Shqiptar, 2008. Pg. 111 
Figure 1. The second (CoPLAN) version of dividing the administrative territory based on the water basins of our country ${ }^{9}$ The division of regions proposed in the second version seems to exclude the geographical-physical element. This division in regions gives each region the possibility to have a connection to the sea, but on the other hand, administers even territories that during winter are blocked by the snow. Thus, these regions, that are supposed to be of a first level of local government and that will have as their attribution the work on regional developing policies, means that they do not have less than the work and attributes of the central government. In this case, there would be two parallel governing bodies, with clashes in visions, concepts and ways of leading that would result in leaving responsibilities to one another. In addition, it is also the negative experience of the function of the districts until now.

From what is seen until now, the discussion of the local government bodies is still open. At least until now there have not been defined the hierarchy, pyramid or taxes of local units, in the frame of the a new administrative-territory division for the country, how these units represent a physical-geographical continuity, which would be the adequate size and the right distribution of population, how the historical heritage and cultural and ethnographic cohesion would be ensured, how the rivers would enable this division, how the natural sources influence, etc, and finally, how this enterprise is supported by all the necessary legal and constitutional changes that will follow.

According to the bill of law "On the administrative - territory division of local governing units in the Republic of Albania", the process of the division will start with the "regions", as basic governing units, where the municipality will be the new center of the local governing unit, and also other new units will be created within the borders of the district, or from territories of two or more districts. The latter will be oriented after the fulfillment of the following criteria:

- The location and economic functions;

- The nearest distance of the territory with the urban center;

- the principle of territory continuity;

- demographic content.

In the regional reconfiguration of Albania, there must be valued different indicators like the geographical features, economical, demographic, regional, cultural, historical and ethnographic features. The assessment made in an integrated way of these indicators would lead to the choice of the best version. In this frame, with the purpose to serve the introduction of the best scientific variation in the division of territories, we are trying to give some map analyses on the demographic, economical, social, historical and cultural situation of the Albanian territory. Regional and local differences of this aspect are many, which can unite or divide regions, nevertheless, it is necessary to take them into consideration and to lead the process of territory reconfiguration in Albania.

\subsection{Demographic and urban dynamics during the period of transition, direction of population movements and areas of the population concentration.}

Defining a minimum universal standard connected to the most efficient value of the population for each commune that must be suppressed is almost e worthless effort (Hellsing, Rydergard 2012). According to the new bill of law based on the demographic criterion for the new units that will be created, the number of population must be at least 30000 for the areas with an average density, 20000 and those with a lower density, 10000 inhabitants. According to some assessments made by INSTAT, it results that local authorities with less than 5000 inhabitants take over $50 \% 10$. Besides this, the number of local unities with 3000 inhabitants or less increased from 91 in 2001, taking 24\%, to 135 in 2011 taking 36\%. This situation explains even the debates made recently regarding the demographic criterion for the new administrative units.

Besides the demographic criterion, some other indicators that must be taken into consideration are the density of the inhabited area, continuity of construction, proportion of new buildings and the existing one, etc. The area inhabited in a commune is the reflection of the demographic charge in a territory. In some communes the number of the inhabitants registered goes against the low density of residencies. This shows that their life is not functional, that a part of the registered community lives somewhere else, in the country or abroad. In this context, the demographic criterion is not enough to make a proper reconfiguration of the territory, but at the same time it is important, because the public services are offered to a certain community, based on the standards provided by the law of urban planning (for example, in an urban center, the parking is allowed near a health center in $15000-30000$ inhabitants, etc.)

${ }^{9}$ Arc GIS 10, Sonila Xhafa

10 INSTAT, Socio-demographic statistics in Albania: selected topics and future developments, Tirana, 2012 


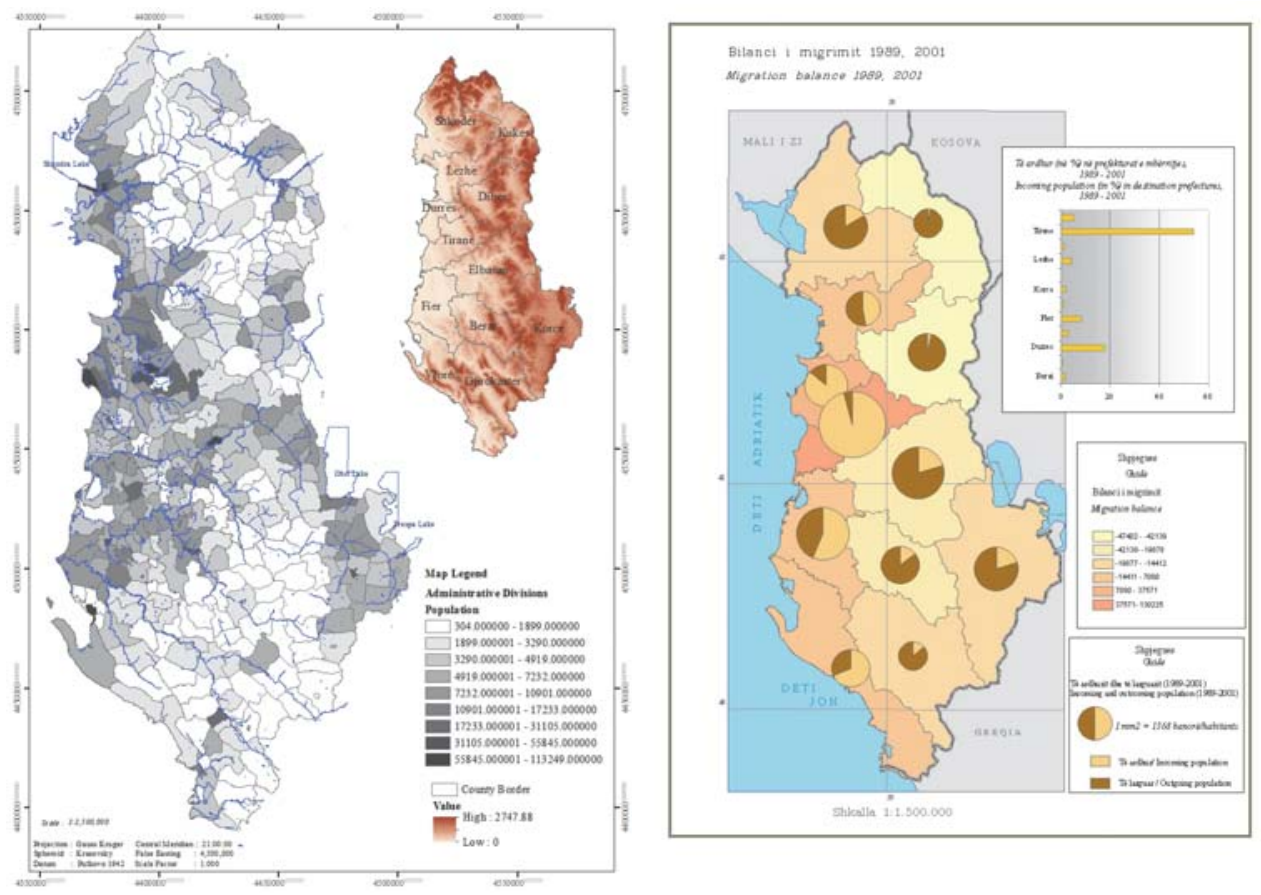

Figure 2. Distribution of population and migration balance in Albania ${ }^{11}$

According to the map, an important part of municipalities resulting in less than 4000 inhabitants. This emphasizes once again the need for territorial reconfiguration, mostly concentrated in northeast and southeast of the country, mainly in the mountainous regions which are characterized by a negative balance of population, losing population for two decades of transition.

\subsection{The criterion of economical functionality (Regionalization of economical type)}

Besides aggregation, communes are defined mainly because of their economical structure. Economical structure can be of a different nature: communes with mainly agricultural activity, those with an important industrial component, or those with tertiary activities. Besides this, rural communes can show combinations among them in the middle of the three sectors. However, this is not e defining criterion. What is defining and necessary in territory division is the efficiency of their economical activity. One of the indicators is also the reflection of these models of employment, income the communes gather from these activities, which is part of the contribution in the GDP of the country, etc.

In this case, it is necessary to make an economical central assessment, or Davies index ${ }^{12}$.

$\mathrm{Ci}=\mathrm{j}(\mathrm{Ni} *(1 / \mathrm{Nj}))$

$i=$ spatial unit (communes)

$\mathrm{j}=$ economic activity

$\mathrm{Nj}=$ total number of jobs in activity $\mathrm{j}$ for all Albania

$\mathrm{Ni}=$ number of jobs in activity $\mathrm{j}$ for spatial unit $\mathrm{i}$

INSTAT has enabled the calculation of this index, whom results are reflected in the polivariable graphics (population, economical activity, administrative position), where in the axis $x$ there are the communes categorized according to the percentage of the population towards the total, and in axis $y$, the percentage of efficiency in economical activity or centralization. Based on this graphic there is a higher positive correlation among these variables, among

${ }^{11}$ Arc GIS 10, Sonila Xhafa

${ }^{12}$ Economic centrality can be defined as spatial economic specialization. According to the concept of advantages of agglomeration, specialized services are concentrated in some central places, where the proximity of other services increases the added value of an enterprise 
institutional and economical centrality of municipalities.

When discussing the urban-rural distinction at the commune level in Albania, we have to consider not only the size and structure of the communes, but also the administrative delimitations. A town with higher administrative functions is characterized from a higher scale of service and economy, than a municipality without this function. On the other hand, a municipality without clear administrative functions indicates that there is a high centralization compared to the communes.

For example, the municipality of Durres has a high Index Davis, because in the corridor Tirane-Durres it is concentrated more than half of the economical and urban functions of the country.

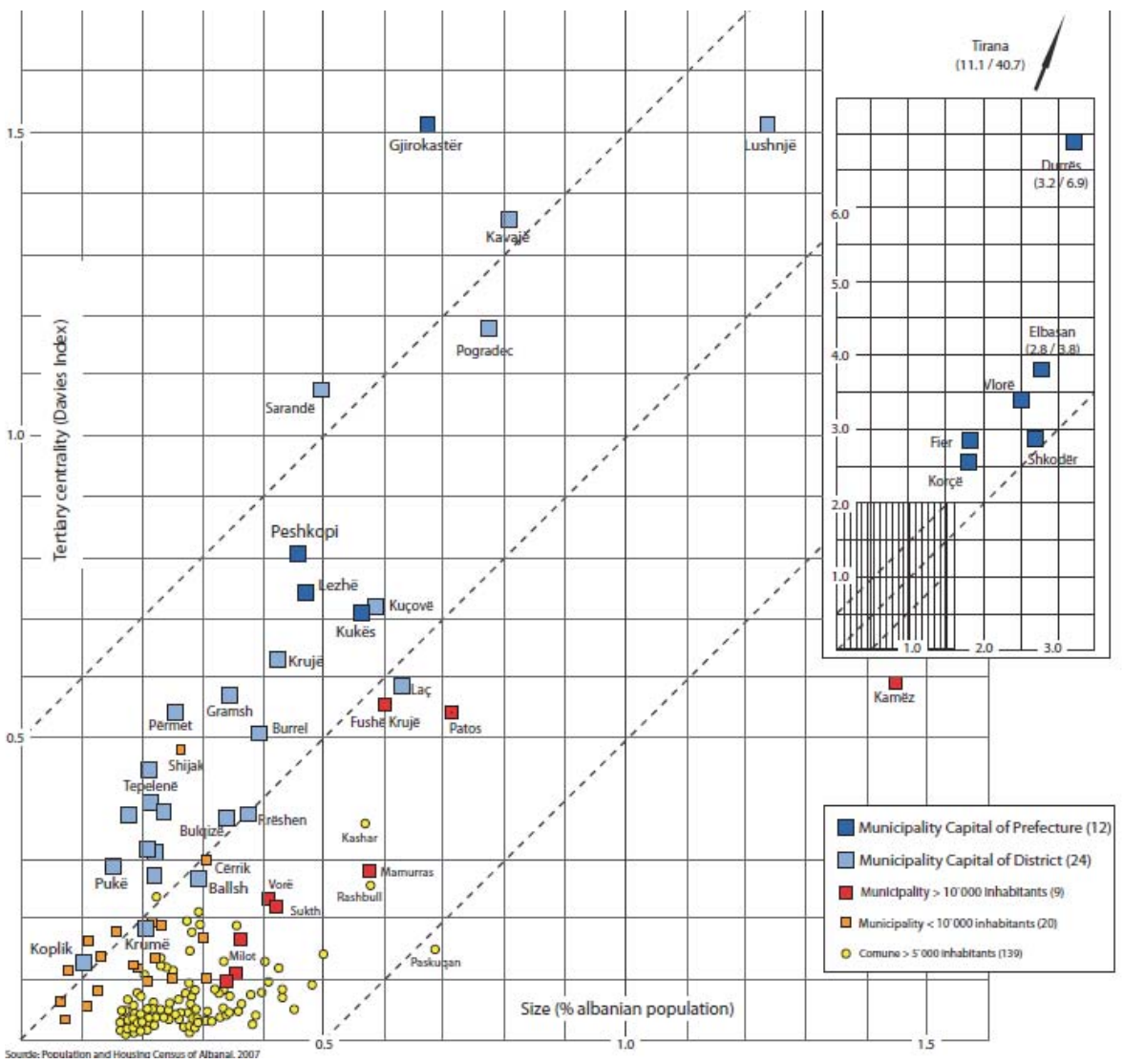

Figure 4. Comparison of population size, institutional status and economic centrality (Davies index) in Albanian communes and municipalities ${ }^{13}$

Municipalities of the second category, with agricultural and tertiary functions, as well as with average sizes are characterized by a higher scale of public services, even though the administrative centralization is not too much developed. Nevertheless, some towns have a low index of centralization, even though they are near very important lines of transport, mainly in towns where the economical activity is connected close to the oil refinery, minerals like in Bulqiza, or agricultural activities (Rreshen, Krume) and sometimes they are combined (Lac).

Meanwhile, other towns, that are near urban centers, like Shijaku, even though they do not possess a favorable administrative axis in the region because of a greater concentration of hotels, restaurants and businesses, which ensure $1 / 3$ of employment in the region.

13 INSTAT, Socio-demographic statistics in Albania: selected topics and future developments, Tirana, 2012 

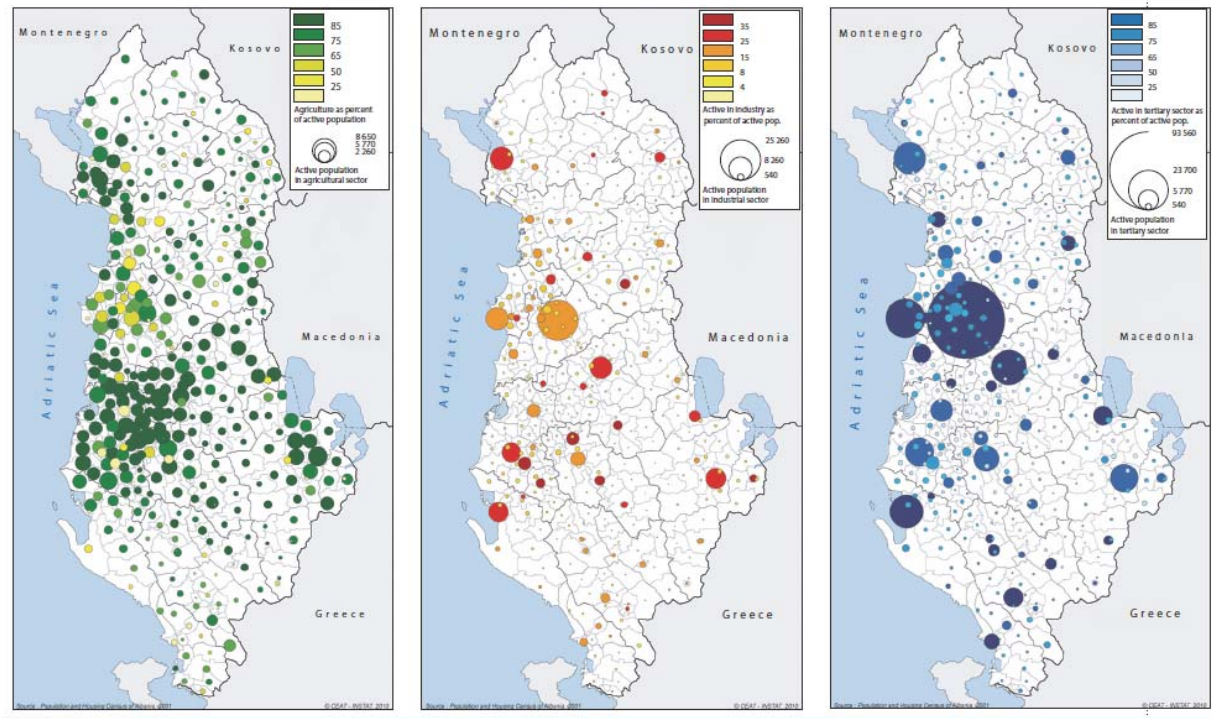

Figure 5. Efficiency of economic activities in Albania ${ }^{14}$

According mapping is noted that the efficiency of economic activities is very small in the north-eastern and south-eastern communes compared to western part of Albania. Beyond that are visible the development regional disparsities in this direction.

Davis index is very important in measuring the scale of economical activity of a municipality or communes, and consequently even in their contribution in GDP. Thus, statistics speak of a low level of getting income from a lot of communes, which causes taxes not to be collected, but also of a low economical efficiency in general, etc. The low economical level of most of the local governing units has made them almost dependable on the transferring of the central power to the central government and investments coming from abroad.

In this context, as final units of local government, they have become a big burden of the state budget. Although this problem is real and serious, treating it only as a new administrative-territory division is very simple. I think that this is not the only reason to condition the new effective administrative-territory division, neither to think that it automatically will lead to the most effective functioning of fiscal and budget policies applied from the future territory units lacked until now.

\subsection{Historical and cultural cohesion}

It must be emphasized that even the historical tradition and heritage are a decisive factor in the administrative -territory division. Social-cultural diversity is expressed beyond local and regional borders: in the middle of the north or south of the country, in the middle of regions and different districts, and in the middle of urban and rural areas, or in the middle of two villages with less than $10 \mathrm{~km}$ away from each other. However, in special areas this diversity is lower, and what caused this is massive migration and communication among different groups.

\subsection{Natural recourses and biodiversity}

Despite its small size, Albania has numerous un renewable natural recourses (oil, gas, coal, natural bitumen, construction raw materials, industrial minerals, etc.) renewable natural resources (water Resources, curative thermal waters, etc.) The main natural assets and biodiversity is reflected in the map below.

14 INSTAT, Socio-demographic statistics in Albania: selected topics and future developments, Tirana, 2012 


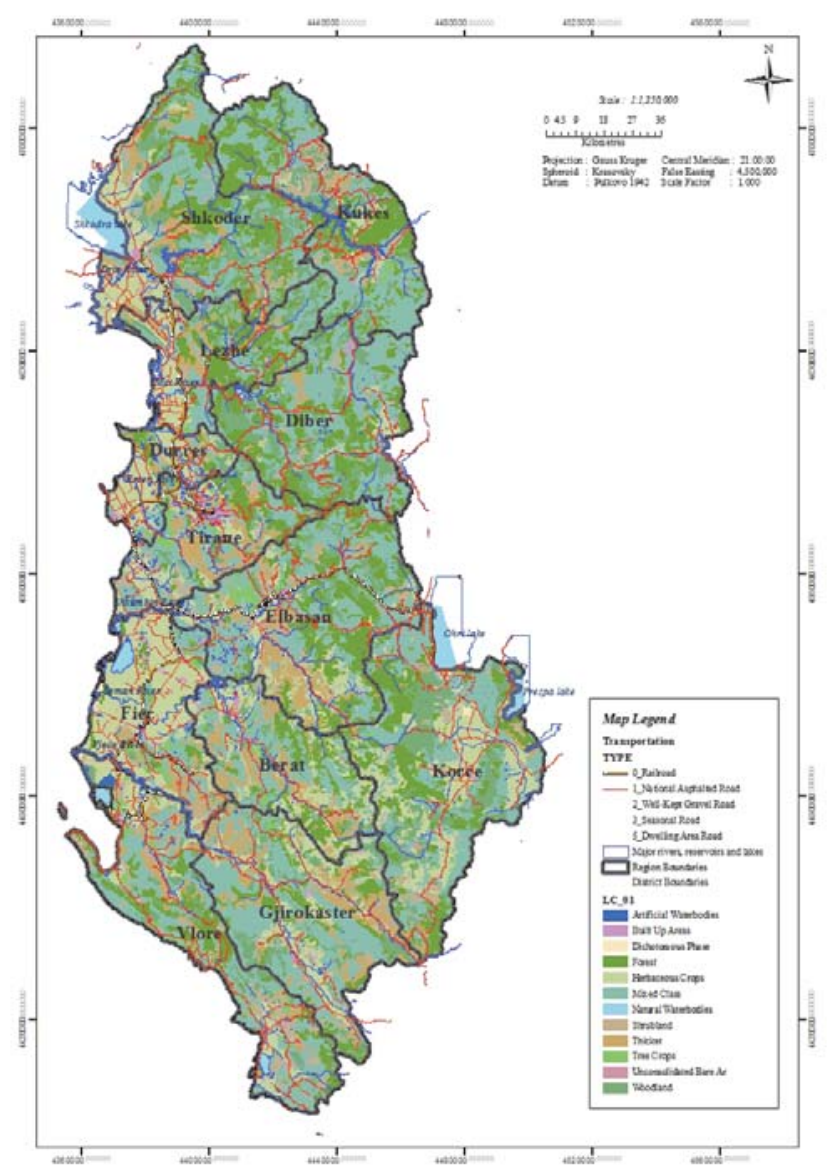

Figure 6. Natural Recourses and Biodiversity ${ }^{15}$

Scientific management of natural resources has been and remains a crucial issue with important implications for the wellbeing of present and future generations. Violation of biodiversity and reduction of natural resources affects seriously sustainable development.

In these conditions, is recommended that the countries territorial reconfiguration respects the principles of sustainable development, to maintain in sustainable way the relationship between economic growth and consumption of natural resources.

Economic development based on future configuration of territory must be accompanied with the rational use of natural resources and the production of limited quantities of waste, maintaining biodiversity, ecosystems and avoiding environmental transformation.

\section{Territory Reforms and Its Effects on the Next Local Elections}

Another important and serious problem is also the impact of the new administrative -territory division will have on the next local elections or the parliamentary ones after that. To give a negative response by saying that this administrative territory division will not influence on the result of the future local or parliamentary elections, or to give positive responses that this division will deform the expected results of the elections, would be just a total lack of knowledge on the concept and gerrymandering practice.

The base of the theory and gerrymandering practice is the reconfiguration of electoral areas (even of the territory divisions) with the only purpose of maximizing the supporting vote. It is known that in any elected unit, every candidate at 
the end of the process analyses the effective votes, the other ones, or the lost ones. On this reasoning, the political party of the candidate aims at reconfiguring the electoral areas (territory) for the next elections. This was taught to us by Elbridge Gerry , former governor of the state of Massachusetts two centuries ago with his famous electoral salamander. As it is noticed, even in the case of Albania, this can be a possible approach, from the political Parties. If it combines or not with the truth, we have to wait for the official reconfiguration of the territory. By laying the map of the previous elections on the new administrative-territory map, as it is promised to be discussed for two months, it would be easy to see if there is or not a gerrymandering tendencies in this fragmentation of the territory of our country.

\section{Concluding Remarks}

The new government has ranked the territory and administrative reform as a top priority, even though it requires time for a wide public discussion. According to the European Cart of Local Governing in the Council of Europe, the reform must guarantee the political, administrative and financial independence of the local government, and the process must be transparent, all-including and consensual. This is important in the context of current situation, because, according to Musgrave, "This, what needs to be done in one case, will depend on the particular set of: the country's political and economic institutions, history and traditions (Musgrave, 2003).

The function of local units called "municipalities", as it is being emphasized until now, causes a lot of problems for this unit, especially on knowing, treating or starting with the urban and rural differentiations of specific social problems they bare. This relation will get worse, by favoring the urban center, causing damage to rural territories within them. At least, until now, the international experience of applying the center-countryside concept suggests this to us.

The statute of Tirana as a separate and particular unit is another debatable problem. What supports this idea serves the experience of primary towns or capitals around the world. Tirana must have a special status in the hierarchy of the new administrative-territory divisions of the country, without Durres and Elbasan. It may function as separated in four regions (Bucharest has 6 ones) by eliminating the 11 units of today. In Tirana there can be included also the suburburban areas, like in London, Moscow, or even in Prishtina or Beograd.

The process of the administrative-territory reform in Albania must respect the provisions of the European Cart of Local Governing in the Council of Europe. It shall also guarantee in particular the political administrative and financial independence of local governing units.

A successful reform seeks complete preparation and taking into consideration the specific situation of the country. A well-thought process of decision-taking is necessary to guarantee the transparency of the process and to ensure the participation of all actors.

The territory reform shall have as a purpose to urge the efforts for regional and economical development and to integrate sectional policies; to enable efficiency in services, in the protection of environmental sources, in stable planning of the territory, in a good social and welfare treatment.

\section{References}

Akademia e Shkencave e Shqipërisë, Fjalori Enciklopedik Shqiptar, 2008.

Council of European Municipalities and Regions, Decentralisation at a crossroads Territorial reforms in Europe in times of crisis, 2013

Çabej E., Shqiptarët midis Perëndimit dhe Lindjes, Tiranë 1994

Hübner D., An agenda for a reformed cohesion policy, A place-based approach to meeting European Union challenges and expectations, April 2009.

INSTAT, Socio-demographic statistics in Albania: selected topics and future developments, Tirana, 2012

Kenneth C., The Original Gerrymander. Political Geography, 2008

Yzeiri E., Gjeografia Politike, Tirana, 2006 